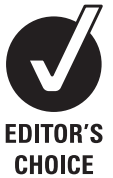

CHOICE
${ }^{1}$ Department of Human Genetics, Nijmegen Centre for Molecular Life Sciences, Radboud University Nijmegen Medical Centre, Nijmegen, The Netherlands

${ }^{2}$ Department of Clinical Genetics, University Medical Centre Nijmegen, Radboud University Nijmegen Medical Centre, Nijmegen, The Netherlands

Correspondence to Dr Lisenka Vissers, Department of Human Genetics-855, Nijmegen Centre for Molecular Life Sciences, Radboud University Nijmegen Medical Centre, P0 Box 9101, Nijmegen 6500 HB, The Netherlands; l.vissers@antrg.umcn.nl

Received 7 September 2009 Revised 10 November 2009 Accepted 16 November 2009

\title{
Genomic microarrays in mental retardation: from copy number variation to gene, from research to diagnosis
}

\author{
Lisenka E L M Vissers, ${ }^{1}$ Bert B A de Vries, ${ }^{1,2}$ Joris A Veltman ${ }^{1}$
}

\section{ABSTRACT}

Structural chromosomal rearrangements can lead to a wide variety of serious clinical manifestations, including mental retardation (MR) and congenital malformations. Over the last few years, rearrangements below the detection level of conventional karyotyping have been proved to contribute significantly to the cause of MR. These so-called copy number variations are now routinely being detected using various high-resolution microarray platforms targeting the entire human genome. In addition to their clinical diagnostic use, the introduction of these high resolution platforms has facilitated identification of novel microdeletion and microduplication syndromes as well as disease genes. The aims of this review are to address several aspects of this revolutionising technology including its application in the diagnostics of MR, the identification of novel microdeletion and microduplication syndromes, and the finding of causative genes for known syndromes. In addition, a future prospect is provided for the detection of disease causing mutations and structural variants by next generation sequencing technologies.

\section{INCREASING THE RESOLUTION TO STUDY THE HUMAN GENOME}

Structural chromosomal rearrangements can lead to a wide variety of serious clinical manifestations, including mental retardation (MR) and congenital malformations. Chromosomal rearrangements larger than $5-10 \mathrm{Mb}$ in size can be detected by conventional karyotyping. A considerable number of clinical disorders, however, is caused by submicroscopic chromosomal rearrangements smaller than $5-10 \mathrm{Mb}$ in size. Depending on the clinical diagnosis, specific (Q)PCR or fluorescent in situ hybridisation (FISH) probe(s) can be used to analyse a specific chromosomal region and confirm a clinical diagnosis. However, an efficient and robust technology was needed to routinely detect rearrangements beyond the level of karyotyping in an unbiased and genome wide fashion.

Genome profiling technologies, such as array based comparative genomic hybridisation (CGH), have dramatically changed the nature of human genome analysis by combining the targeted high resolution approach of the FISH technology and the whole genome approach of the karyotyping technology. Initially, genomic microarrays were developed in academia and contained mostly genomic fragments obtained from large insert genomic clones, mainly bacterial artificial chromosomes (BACs). ${ }^{12}$ Different clone sets have been used, the most popular ones containing one clone per $1 \mathrm{Mb}$ or later on using a tiling resolution clone set of approximately 30000 clones, covering the genome with one clone per $100 \mathrm{~kb}^{3-10}$ In the last few years genomic microarray production has been taken over by private enterprises and many companies are now offering microarrays for genome wide copy number profiling. With the increasing resolution of the different array platforms, detection of smaller and smaller genomic copy number variations (CNVs) has become possible (see table 1 for an overview of most popular genomic microarray platforms).

In 2007, a novel method was developed to estimate the ability of a microarray to reliably detect genomic CNVs of different sizes and types all over the genome. ${ }^{11}$ The method is based on the following variables: (1) the genomic coverage of the platform; (2) an estimate of the noise in the microarray experiment (the standard deviation of the test-over-reference ratio of the autosomal targets); (3) an estimate of a single copy number loss (ratio of the chromosome $\mathrm{X}$ unique regions of sex mismatch experiments); and (4) the desired statistical power. Four widely used high density genomic microarray platforms for CNV detection were tested for their performance, including $32 \mathrm{k}$ BAC arrays, 100 and 250k single nucleotide polymorphism (SNP) microarrays and 385k oligonucleotide arrays. By doing so, it was found that the high density oligonucleotide platforms are superior to the BAC platform for the genome wide detection of CNVs smaller than $1 \mathrm{Mb}$. The capacity to reliably detect single CNVs below $100 \mathrm{~kb}$, however, at that time appeared to be limited for all platforms tested. These analyses provided a first objective insight into the true capacities and limitations of different genomic microarrays to detect and define CNVs. Moreover, the study showed that, depending on the microarray platform being used and the pre-processing steps being performed before CNV detection, 3-18 adjacently located targets were required for reliable detection of single copy number losses or gains. In addition, the analysis revealed an unexpected platform dependent difference in sensitivity to detect a single copy number loss and a single copy number gain. Single copy number gains are more difficult to detect due to the fact that the intensity ratios of single copy number gains (in theory a test-over-reference ratio of 1.5 , or 0.58 in log2 scale) are sometimes close to the experimental noise level of a microarray platform. In conclusion, this study showed that genomic microarray platforms vary in their capacity to 
Table 1 Overview of the latest generation of commercially available microarrays for copy number variation (CNV) detection

\begin{tabular}{llll}
\hline Microarray vendor & Catalogue whole genome array & Technology & Total number of copy number markers \\
\hline Affymetrix & Cytogenetics Whole Genome 2.7M array & $\begin{array}{l}\text { Single colour hybridisation, CNV and } \\
\text { genotyping }\end{array}$ & $\begin{array}{l}2761979 \text { oligonucleotides, of which } \\
400103 \text { are single nucleotide } \\
\text { polymorphism (SNP) specific }\end{array}$ \\
Agilent & Human High-Resolution Discovery 1*1M & Two-colour hybridisation, CNV only & 963331 oligonucleotides \\
Illumina & Human 1M-duo BeadChip & $\begin{array}{l}\text { Single-colour hybridisation, CNV and } \\
\text { genotyping }\end{array}$ & 1199187 oligonucleotides, majority SNP \\
NimbleGen & Human CGH 2.1M & Two-colour hybridisation, CNV only & 2100000 oligonucleotides \\
\hline
\end{tabular}

reliably detect CNVs of different sizes and different types. This should be taken into account for estimating the practical resolution of a platform to detect genomic CNVs. At the time of this analysis (2007) many of the platforms still contained considerable gaps in coverage, mostly due to the fact that these regions contained no unique sequences and were often excluded from the SNP microarray design because of Mendelian inconsistencies.

Most of the above mentioned problems have now been solved and companies have released microarrays containing more than two million oligonucleotides targeting random sequences, SNPs, or combinations thereof (table 1). These oligonucleotides have been more evenly spaced across the genome, and optimised protocols are now available for the quantitative detection of CNVs. With this, CNV detection can now reliably be performed at the kilobase level, resulting in the detection of hundreds of CNVs per individual. ${ }^{12-17}$ These advances have made genomic profiling technology an excellent tool for clinical genetic diagnostic applications as well as for fundamental genome research.

\section{APPLICATION OF GENOMIC PROFILING IN THE DIAGNOSTICS OF MR}

Genomic microarrays have been extensively used in studying the genetic causes of MR and this disorder can therefore be considered a model disease to study the clinical consequences of CNVs. MR occurs in $2-3 \%$ of newborns in the general population, but, in most cases, its cause has remained elusive. ${ }^{18} 19$ Establishing the cause in a mentally retarded individual improves clinical management and facilitates genetic counselling of the family. Chromosome abnormalities are detectable by microscopic analysis of chromosomes isolated from peripheral blood lymphocytes in $\sim 5 \%$ of patients with unexplained MR. ${ }^{20}{ }^{21}$ Molecular cytogenetic techniques, such as FISH and multiplex ligation dependent probe amplification (MLPA), ${ }^{22}$ have shown that causative submicroscopic rearrangements of the subtelomeric regions can be found in $\sim 5 \%$ of patients with human malformations and $M R^{23-26}$ These results for the subtelomeric regions indicated early on that submicroscopic rearrangements such as CNVs may be a more common cause of MR than microscopically visible rearrangements.

From its introduction using genome wide $1 \mathrm{Mb}$ BAC arrays, array $\mathrm{CGH}$ has proven useful in the diagnostics of MR with the detection of causative microdeletions and/or duplications in $\sim 10 \%$ of individuals with MR with or without additional congenital anomalies. ${ }^{89}$ Additional studies have provided insight into the quality and reproducibility of the procedure, the need for validation of the microarray data by independent technologies such as FISH or MLPA, as well as the way to translate these data into clinical practise. ${ }^{7} 27$ The clinical usefulness of molecular karyotyping was further substantiated in larger, less selected, cohorts of individuals with $\mathrm{MR}$ using $1 \mathrm{Mb}$ resolution BAC arrays, ${ }^{46}$ tiling resolution BAC arrays, ${ }^{10}$ or $100 \mathrm{k}$ SNP arrays. ${ }^{12}$ In the latter tiling resolution BAC array study, reproducible DNA copy number changes were detected in $97 \%$ of patients. The majority of these alterations appeared to be inherited from phenotypically normal parents, which reflected normal CNVs in the human population. In $10 \%$ of patients rare de novo alterations considered to be clinically relevant were found: seven deletions and three duplications, varying in size from $540 \mathrm{~kb}$ to $12 \mathrm{Mb}$ and occurring scattered throughout the genome.

Many similar studies have been published since (reviewed by Koolen et al, ${ }^{3}$ Veltman, ${ }^{28}$ and Knight and Regan ${ }^{29}$. When taking all studies together, two main conclusions can be drawn: (1) in addition to submicroscopic subtelomeric chromosome imbalances, rare, de novo, submicroscopic interstitial chromosome imbalances or $\mathrm{CNVs}$ are responsible for a considerable proportion of cases with MR varying between 5-20\%, depending on the clinical pre-selection of the individuals; and (2) these rare de novo CNVs occur all over the genome. When comparing these results to standard GTG banded karyotyping, the diagnostic yield of array $\mathrm{CGH}$ in the general population of patients with $\mathrm{MR}$ is at least twice as high.

Next to the apparent causative alterations, a large number of inherited submicroscopic CNVs without evident clinical consequences have been detected by array based methods, in patients as well as in control populations. ${ }^{5} 1030-40 \mathrm{CNV}$ is now considered as a common form of structural genomic variation with ultrahigh resolution microarrays and sequencing approaches identifying $>1000 \mathrm{CNV}$ s in a single individual. ${ }^{41}$ Current clinical interpretation therefore involves an analysis of the frequency of CNVs in unaffected control cohorts as well as parental analysis (see Lee et $a l^{42}$ as well as Koolen $e t a l^{3}$ for a review of literature on the application of genomic microarray to MR and a practical workflow for diagnostic applications). The identification of a (1) relatively large, (2) rare, and (3) de novo CNV in such a patient is a strong indicator of clinical significance, as this combination is rare in the normal population. ${ }^{5} 434$ These indicators are specifically helpful if the potential causative CNV can readily be detected. An additional level of complexity in interpreting array data is the presence of mosaicism, in which case the initial identification of such potential causative CNV may be hampered. In a comprehensive study of 638 neonates with various birth defects, array analyses detected 12 (1.9\%) mosaic pathogenic variants. ${ }^{45}$ The notion that MR CNVs may occur postzygotically underscores the importance for automated detection of mosaicisms. ${ }^{46}$

\section{IDENTIFICATION OF RECURRENT MICRODELETION AND MICRODUPLICATION SYNDROMES}

The possibility to perform genome wide CNV studies in patients with MR has substantially increased the chance to identify novel 'microdeletion/microduplication syndromes'. In general, the identification of novel syndromes is based on an accurate phenotype-genotype correlation. From an historical perspective, this correlation relied on a detailed and accurate phenotypic 
description of the patients after which overlapping chromosomal rearrangements were uncovered. Nowadays, obtaining a genotype has become much easier and, in addition, has never been more accurate. As a result, the identification of novel syndromes may start with the identification of overlapping genotypes - that is, a 'genotype first' approach, ${ }^{47}$ or 'reverse phenotypics', in which patients are characterised by a similar genomic aberration before a common clinical presentation is defined. This approach has proven to be successful considering the growing list of microdeletion/microduplication syndromes (table 2).

The 17q21.31 microdeletion syndrome was the first microdeletion syndrome identified through this approach, simultaneously described by three groups. ${ }^{48-50}$ Recurrent overlapping de novo microdeletions in 17q21.31 were identified in patients with MR using array CGH and MLPA. Clinical comparison of these patients revealed pronounced phenotypic similarities-that is MR, hypotonia and characteristic facial features, including a long hypotonic face with upslanting palpebral fissures, epicanthic folds, ptosis, large prominent ears, a tubular or pear shaped nose with a bulbous nasal tip, long columella with hypoplastic alae nasi and a broad chin. ${ }^{48}$ Other clinically important features include epilepsy, heart defects and kidney/ urologic anomalies. The identification of more patients with the same aberration showed that the 17q21.31 microdeletion syndrome is a frequent cause of MR with an estimated prevalence of $\sim 1$ in 16000, and allowed the detailed clinical and molecular delineation this syndrome. ${ }^{51}$ Currently, it is still unknown whether the 17q21.31 microdeletion syndrome can be caused by a mutation in one single gene located within the deletion interval (MAPT, CRHR1, IMP5 and STH). Efforts in sequencing the coding regions of the MAPT gene in 122 patients resembling the 17q21.31 deletion phenotype but without the deletion have so far not revealed any mutations. ${ }^{48-51}$

Another example of a clinically well recognisable microdeletion syndrome is the $15 \mathrm{q} 24$ microdeletion. Initially only four individuals with submicroscopic overlapping deletions of the 15q24 region were ascertained by screening a total of $\sim 1200$ individuals with idiopathic MR. ${ }^{10} 52$ They shared several clinical features, including $M R$, growth retardation, microcephaly, digital abnormalities, genital abnormalities, hypospadias and loose connective tissue. In addition, similar facial dysmorphisms were noted, including high frontal hairline, broad medial eyebrows, downslanting palpebral fissures and a long philtrum, indicating that the $15 \mathrm{q} 24$ deletions represent a clinical syndrome. ${ }^{52}$ A further $15 \mathrm{q} 24$ microdeletion case showed similar

Table 2 Recurrent interstitial microdeletion/duplications associated with mental retardation

\begin{tabular}{|c|c|c|c|c|}
\hline Name & Size $(\mathbf{M b})^{*}$ & LCR & MIM & Clinical features \\
\hline 1q21.1 microdeletion & 1.1 & + & 612474 & $\begin{array}{l}\text { Mild-to-moderate MR, MC, cardiac abnormalities, cataracts, clear incomplete } \\
\text { penetrance }\end{array}$ \\
\hline 1q21.1 microduplication & 1.1 & + & 612475 & Autism or autistic behaviours, mild to moderate MR, microcephaly, mild FD \\
\hline 1q41q42 microdeletion & 1.2 & - & - & MR, seizures, various dysmorphisms, cleft palate, diaphragmatic hernia \\
\hline 2p15q16.1 microdeletion & 3.9 & - & - & $\begin{array}{l}\text { MR, MC, receding forehead, ptosis, telecanthus, short palpebral fissures, } \\
\text { downslanting palpebral fissures, broad/high nasal bridge, long/straight eyelashes, } \\
\text { smooth and long philtrum, smooth upper vermillion border, everted lower lip, high } \\
\text { narrow palate, hydronephrosis, optic nerve hypoplasia }\end{array}$ \\
\hline $3 q 29$ microdeletion & 1.6 & + & 609425 & MR, mild FD, including high nasal bridge and short philtrum \\
\hline $3 q 29$ microduplication & 1.6 & + & 611936 & Mild/moderate MR, MC, obesity \\
\hline 7q11.23 microduplication & 1.5 & + & 609757 & MR, speech and language delay, autism spectrum disorders, mild FD \\
\hline 9q22.3 microdeletion & 6.5 & - & - & MR, hyperactivity, overgrowth, trigonocephaly, macrocephaly, FD \\
\hline 12q14 microdeletion & 3.4 & - & - & Mild MR, failure to thrive, proportionate short stature and osteopoikilosis \\
\hline $14 q 11.2$ microdeletion & 0.4 & - & - & $\begin{array}{l}\text { MR, widely spaced eyes, short nose with flat nasal bridge, long philtrum, Cupid's } \\
\text { bow of the upper lip, full lower lip, auricular anomalies }\end{array}$ \\
\hline $15 q 13.3$ microdeletion & 1.5 & + & 612001 & MR, epilepsy, hypotonia, short stature, microcephaly and cardiac defects \\
\hline $15 q 24$ microdeletion & 1.7 & + & - & $\begin{array}{l}\text { MR, growth retardation, MC, digital abnormalities, genital abnormalities, } \\
\text { hypospadias, loose connective tissue, high frontal hairline, broad medial eyebrows, } \\
\text { downslanted palpebral fissures, long philtrum }\end{array}$ \\
\hline 16p11.2 microdeletion/duplication & 0.6 & + & 611913 & Association with MR, autism, schizophrenia \\
\hline 16p11.2p12.2 microdeletion & 7.1 & + & - & $\begin{array}{l}\text { MR, flat facies, downslanting palpebral fissures, low-set and malformed ears, eye } \\
\text { anomalies, orofacial clefting, heart defects, frequent ear infections, short stature, } \\
\text { minor hand and foot anomalies, feeding difficulties, hypotonia }\end{array}$ \\
\hline 16p13.1 microduplication & 1.6 & + & - & Association with autism, significance uncertain \\
\hline 16p13.1 microdeletion & 1.6 & + & - & MR, MC, epilepsy, short stature, phenotypic variability \\
\hline 17p11.2 microduplication $†$ & 3.7 & + & 610883 & $\begin{array}{l}\text { MR, infantile hypotonia, failure to thrive, autistic features, sleep apnoea, and } \\
\text { structural cardiovascular anomalies }\end{array}$ \\
\hline 17q21.31 microdeletion & 0.5 & + & 610443 & $\begin{array}{l}\text { MR, hypotonia, long hypotonic face with ptosis, large and low set ears, tubular or } \\
\text { pear shaped nose with bulbous nasal tip, long columella with hypoplastic alae nasi, } \\
\text { broad chin }\end{array}$ \\
\hline $19 q 13.11$ microdeletion & 0.7 & - & - & $\begin{array}{l}\text { MR, pre- and postnatal growth retardation, primary microcephaly, hypospadias, } \\
\text { ectodermal dysplasia including scalp aplasia, dysplastic nails and dry skin }\end{array}$ \\
\hline 22q11.2 microduplication & 3.7 & + & 608363 & $\begin{array}{l}\text { Highly variable. MR, FD, for example widely spaced eyes and downslanting } \\
\text { palpebral fissures, velopharyngeal insufficiency, conotruncal heart disease }\end{array}$ \\
\hline $22 q 11.2$ distal microdeletion & $1.4-2.1$ & + & 611867 & $\begin{array}{l}\text { MR, prematurity, prenatal/postnatal growth delay, mild skeletal abnormalities, } \\
\text { arched eyebrows, deep set eyes, smooth philtrum, thin upper lip, hypoplastic alae } \\
\text { nasi, small pointed chin }\end{array}$ \\
\hline Xq28 microduplication & $0.4-0.8$ & - & - & $\begin{array}{l}\text { MR, severe hypotonia, progressive lower limb spasticity, absent or very limited } \\
\text { speech }\end{array}$ \\
\hline
\end{tabular}

FD, facial dysmorphisms; LCR, low copy repeat; MC, microcephaly; MR, mental retardation.

*Common region.

†Potocki-Lupski syndrome. 
phenotypic features, although microcephaly and growth deficiency were absent. ${ }^{53}$ The deletions in the patients varied from 1.7-3.9 $\mathrm{Mb}$ in size. An additional four new deletion patients were identified after screening a cohort of 9000 diagnostic cases. ${ }^{54}$ Interestingly, this latter study presented two patients with a duplication of the same region. The phenotype of these patients partially overlapped with the microdeletion phenotype. The breakpoints were located in nearly identical segmental duplications, which turned non-allelic homologous recombination into the most likely underlying molecular mechanism of occurrence. ${ }^{54}$

Both the $17 \mathrm{q} 21$ and the $15 \mathrm{q} 24$ microdeletion syndromes are examples where the initial identification of the (overlapping) microdeletions led to a consistent and well recognisable clinical entity. However, an increasing number of genomic loci has been recently reported with variable inheritance and penetrance, challenging clinical interpretation. Examples of this have been reported for CNVs at $1 \mathrm{q} 21.1,{ }^{55}{ }^{56} 15 \mathrm{q} 13.3,{ }^{57}{ }^{58}$ and $16 \mathrm{p} 13.11 .^{59} 60$ In more detail, the recurrent $1.35 \mathrm{Mb}$ deletion within $1 \mathrm{q} 21.1 \mathrm{was}$ initially identified in 52 persons from screening over 21000 patients with unexplained MR, autism and/or congenital anomalies. ${ }^{55} 56$ The phenotype varied considerably and included mild-to-moderate MR, microcephaly, cardiac abnormalities and cataracts. Remarkably, several unaffected deletion carriers were noted, underscoring the clinical variability. Enrichment of 1q21.1 deletions in persons with schizophrenia was also reported, suggesting a role in psychiatric disorders as well. ${ }^{61} 62$ The reciprocal microduplication involving 1q21.1 was associated with autism or autistic behaviours, and common phenotypic features of the duplication carriers included mild to moderate $M R$, macrocephaly or relative microcephaly, and mild dysmorphic features. ${ }^{55} 56$ Also this microduplication was identified in apparently normal individuals.

The clinical variability for the $15 \mathrm{q} 13.3$ microdeletion is of a similar order to the 1q21.1 microdeletion. Initially, nine affected individuals were identified in a large cohort of individuals with MR of unknown aetiology. These patients included six probands: two with de novo 15q13.3 deletions, two who inherited the deletion from an affected parent, and two with an unknown mode of inheritance. ${ }^{57}$ The patients had MR, epilepsy and variable facial and digital dysmorphisms in common. The recurrent $1.5 \mathrm{Mb}$ deletion encompasses six genes, including a candidate gene for epilepsy (CHRNA7). The clinical variability of the $15 q 13$ microdeletion was underscored by other studies showing a clinical spectrum varying from non-pathogenic to a severe outcome with a highly variable intra- and inter-familial phenotype. ${ }^{58}$ In addition to cognitive impairment the phenotype might also include features of autism spectrum disorders and a variety of neuropsychiatric disorders. ${ }^{63}$ In order to further clinical interpretation, the continuous collection of (disease causing) CNVs and their associated phenotypes in databases such as ECARUCA (http://www.ecaruca.net) and DECIPHER (https://decipher.sanger.ac.uk/application/) is of major importance, not only for the confirmation of pathogenicity, but also for the proper counselling of patients and families.

\section{RESOLVING THE GENETIC CAUSE OF KNOWN SYNDROMES}

In addition to screening individuals with $M R$ and defining new microdeletion and microduplication syndromes, high resolution genome profiling technologies may also facilitate the identification of disease genes underlying known syndromes for which the genetic cause has remained elusive. The specific phenotype observed in patients with such syndromes allows for a stringent pre-selection of patients whose DNA can subsequently be interrogated using such high resolution genome profiling techniques. The first syndrome for which the genetic basis was resolved by this approach was CHARGE syndrome. ${ }^{64}$

CHARGE syndrome (MIM 214800) is an autosomal dominant disorder with a prevalence of one in $10000 .^{65}$ The acronym CHARGE was first proposed in 1981 based on the cardinal features identified when the association was clinically delineated: Coloboma, Heart malformation, choanal Atresia, Retardation of growth and/or development, Genital anomalies, and Ear anomalies. ${ }^{66}$ Most cases of CHARGE syndrome are sporadic, but several aspects of this condition, including the existence of rare familial cases and a high concordance rate in monozygotic twins, supported the involvement of a genetic factor. Rare de novo cytogenetic abnormalities have been described, but no specific locus had been identified before 2004. Also, systematic genome scans by conventional metaphase CGH and microsatellite analyses did not reveal a common genetic cause, nor did targeted sequencing of candidate genes such as PAX2 and PITX2. With the availability of microarray based approaches, new unbiased, genome wide screens were performed hypothesising that microdeletions and/or microduplications might be the underlying cause of CHARGE syndrome. ${ }^{64}$ Initial screening of two patients with CHARGE syndrome on a $1 \mathrm{Mb}$ BAC array revealed a microdeletion of $\sim 5 \mathrm{Mb}$ in one of the patients at chromosome locus 8q12. Interestingly, an individual with CHARGE syndrome with an apparently balanced chromosome 8 translocation had been reported previously, with the breakpoint estimated within the $8 \mathrm{q} 12$ region. ${ }^{67}$ Array CGH analysis of this translocation unravelled two interspersed microdeletions, overlapping with the microdeletion of the first patient. Subsequent array analyses on a tiling resolution chromosome 8 BAC array of 17 additional CHARGE patients did not show any additional microdeletions. As such, it was reasoned that mutations could be present in these patients in one of the genes residing in the shortest region of deletion overlap. Sequence analysis of nine genes located within this region revealed causative mutations in CHD7, a novel member of the chromodomain helicase DNA binding gene family, in the majority of individuals with CHARGE syndrome without deletions. Based on these results, it was concluded that CHARGE syndrome is caused by haploinsufficiency of the CHD7 gene, either by microdeletions encompassing the CHD7 gene, or by mutations within this gene. $^{64}$

A second well illustrated example of gene discovery through deletion and/or translocation mapping is the discovery of the euchromatin histone methyl transferase 1 (EHMT1) gene causing 9q subtelomeric deletion syndrome (MIM 610253). Submicroscopic subtelomeric deletions of chromosome 9q (9qSTDS) are associated with a recognisable MR syndrome, with clinical features including severe MR, hypotonia, brachy(micro)cephaly, epileptic seizures, flat face with hypertelorism, synophrys, everted lower lip, carp mouth with macroglossia, and heart defects. ${ }^{68-70}$ The identification of the molecular cause of 9 qSTDS started with the initial FISH screening of subtelomeric rearrangements in 12 patients narrowing down the commonly deletion region to $\sim 1.2 \mathrm{Mb}$ interval. ${ }^{70}$ Subsequently, this region was further reduced to an $\sim 700 \mathrm{~kb}$, still containing at least five genes and several expressed sequence tags (ESTs). ${ }^{71}$ The first evidence that 9qSTDS was not a contiguous gene syndrome, but a single gene disorder, came from the characterisation of the breakpoints of a balanced translocation $t(X ; 9)(p 11.23 ; q 34.3)$ in a patient presenting with typical features of $9 \mathrm{qSTDS}$. Molecular analyses revealed that the chromosome 9 breakpoint disrupted the EHMT1 gene in intron 9. ${ }^{72}$ Additional evidence for the causative 
role of EHMT1 was provided by deletion screening and sequence analysis of the gene in 23 patients with a clinical presentation reminiscent of $9 \mathrm{qSTDS} .^{73}$ Of these 23 patients, three showed a deletion including the EHMT1 gene. However, more importantly, mutation analysis revealed de novo mutations in the EHMT1 gene in two additional patients. With this discovery, it was established that haploinsufficiency, of the EHMT1 gene, either by deletion or mutation, leads to 9qSTDS. ${ }^{69}$

Placed in a broader perspective, array based genomic profiling may be best suited for resolving the genetic cause of known syndromes that involve haploinsufficiency as the disease causing mechanism (table 3). ${ }^{74}$ Whether the latter is the case may be difficult to predict from the phenotype alone. Also, it is difficult to predict how many patients need to be included in the study to find a microdeletion. For instance, although both can be considered single gene disorders, for CHARGE syndrome CHD7 gene mutations are prevailing over gene deletions whereas deletions involving EHMT1 are more prevalent than mutations in $9 \mathrm{qSTDS}$. This also shows that it is challenging to predict whether a syndrome is a single gene disorder, a contiguous gene syndrome, a genomic disorder, or a combination thereof.

\section{FUTURE PERSPECTIVE ON DISEASE GENE AND CNV IDENTIFICATION IN CLINICAL GENETICS}

The ultimate resolution to screen the human genome for disease causing mutations and CNVs is at the base pair level. Major advances in DNA sequencing technologies, collectively termed next generation sequencing (NGS) technologies, are now enabling the comprehensive analysis of whole genomes, transcriptomes and interactomes. ${ }^{40-81}$ Currently, NGS comprises three main non-Sanger based sequencing methods: (1) pyrosequencing (Roche 454 technology); (2) sequencing with reversible terminators (Solexa technology); and (3) sequencing by ligation (SOLiD technology). ${ }^{75}$ The main differences between the methods are read length, number of reads per run, and the costs involved. ${ }^{76}$ Although the method of choice is based upon the research/diagnostic question, all NGS methods are in principle capable of detecting both single base mutations and structural variation (figure 1).

With shotgun sequencing, the genome is shredded into smaller fragments of DNA which can be massively sequenced in parallel. Next, the sequenced fragments are assembled into contigs based on the overlap in the sequence reads (de novo assembly) or, alternatively, are aligned to a reference genome. In the latter situation, single base pair changes compared to a reference genome can be identified and as such may lead to disease gene identification. Proof-of-principle studies, using the autosomal dominant Freeman-Sheldon syndrome and X-linked $M R$, have already shown that causative point mutations can be identified using this approach. ${ }^{80} 81$ CNV can be identified by differences in read depth-for example, the number of reads mapping to a specific genomic locus also referred to as coverage (figure 1C). For instance, for heterozygous deletions half the number of reads should be expected compared to the surrounding regions where two copies are present, whereas for duplications 1.5 times the number of sequence reads should be present. Additional evidence for copy number variants is provided by so-called 'split-reads' in which one part of the sequence read maps to one side of the deleted or duplicated interval, whereas the remainder of the sequence read maps to the other side of the interval.

Currently, the most specific NGS application to identify CNV is paired-end mapping or mate-pair library sequencing, as this application directly provides detailed positional information. ${ }^{78} 79$ This application does not only identify unbalanced variants but also balanced rearrangements, such as translocations and inversions. For mate-pair runs, genomic DNA is randomly sheared and size selected. After several processing steps, shotgun reads are obtained by sequencing both ends of the size selected DNA library. This positional information determined by the size selection constrains the placement of paired reads within the reference genome. Deviations from this expected size distribution may point to structural variation (figure 1D). For example, fragments sequenced from $3 \mathrm{~kb}$ library are expected to map $\sim 3 \mathrm{~kb}$ apart when mapped back onto the reference genome, whereas fragments mapping $\sim 100 \mathrm{~kb}$ apart may point to a deletion in the DNA library tested. Additionally, mate-pairs with different strand location, orientation or mapping positions to different chromosomes may indicate inversions and translocations. Interestingly, paired-end mapping strategies have identified numerous structural variants currently not annotated in the reference genome, suggesting that the reference genome is still incomplete. $^{79}$

\section{CONCLUSIONS}

In February 2001, the International Human Genome Sequencing Consortium and Celera Genomics reported the first draft sequence of the human genome. ${ }^{82}$ In the years that followed, this draft sequence has been instrumental for the systematic analysis of the human genome, including the identification/ annotation of novel genes, the elucidation of regional differences in genome composition, and the identification of SNPs. In

Table 3 Dosage sensitive genes identified through microdeletion and/or duplication mapping strategies

\begin{tabular}{|c|c|c|c|c|c|}
\hline Syndrome & Chromosome & Size & Gene(s) involved & MIM & Reference \\
\hline Cystinuria with mitochondrial disease & $\operatorname{del}(2)(p 16)$ & $179 \mathrm{~kb}$ & SLC3A1, PPM1B, KIAA0436 & 606407 & Parvari et al ${ }^{90}$ \\
\hline Adrenal hyperplasia with hypermobility & $\operatorname{del}(6)(p 21)$ & $33 \mathrm{~kb}$ & TNBX, CYP21A & - & Koppens et $a l^{91}$ \\
\hline CHARGE syndrome & $\operatorname{del}(8)(q 12)$ & $2300 \mathrm{~kb}$ & CHD7 & 214800 & Vissers et $\left.a\right|^{64}$ \\
\hline 9q subtelomeric deletion syndrome & $\operatorname{del}(9)(q 34)$ & Diverse & EHMT1 & 610253 & Kleefstra et $a l^{72}$ \\
\hline Potocki-Shaffer syndrome & del(11)(p11.2) & $2100 \mathrm{~kb}$ & EXT2, ALX4 & 601224 & Potocki et al ${ }^{93}$ \\
\hline $\begin{array}{l}\text { Infantile hyperinsulinism enteropathy and } \\
\text { deafness }\end{array}$ & $\operatorname{del}(11)(p 15 p 14)$ & $122 \mathrm{~kb}$ & USH1C, ABCC8, KCNJ11 & 606528 & Bitner-Glindzicz et al ${ }^{94}$ \\
\hline Peters Plus syndrome & del(13)q12.3q13.1) & $1500 \mathrm{~kb}$ & B3GALTL & 261540 & Lesnik Oberstein et al ${ }^{96}$ \\
\hline $\begin{array}{l}\text { Tuberous sclerosis polycystic kidney } \\
\text { disease }\end{array}$ & del(16)(p13) & $87 \mathrm{~kb}$ & TSC2, PKD1 & 173900 & Brook-Carter et al ${ }^{97}$ \\
\hline Potocki-Lupski syndrome & $\operatorname{dup}(17)(p 11.2 p 11.2)$ & $3700 \mathrm{~kb}$ & RAl1 & 610883 & Potcoki et al/98 \\
\hline Alport leiomyomatosis & $\operatorname{del}(X)(q 22.3)$ & $133 \mathrm{~kb}$ & COL4A5, COL4A6 & 301050 & Zhou et al ${ }^{99}$ \\
\hline MECP2 duplication syndrome & $\operatorname{dup}(X)(q 28)$ & Variable & MECP2 & - & Van Esch et al ${ }^{100}$ \\
\hline
\end{tabular}


Figure 1 Copy number detection using array based platforms $(A, B)$ is based on the ratio for hybridisation signal intensity between control and patient DNA. In case of bacterial artificial chromosome (BAC) microarray (A), control and patient DNAs are simultaneously hybridised to the same array, allowing for a direct signal intensity comparison. In case of single nucleotide polymorphism (SNP) arrays (B), this signal intensity comparison is performed in silico as control and patient DNA are hybridised to individual arrays. Copy number detection using next generation sequencing $(C, D)$ depends directly on the read depth of the individual sequence reads derived from patient DNA (C). Read depth within a heterozygous deletion will contain half the number of sequence reads compared to flanking genomic regions containing two genomic copies. In addition, 'split-reads' will be present,

indicating the breakpoints of the deletion interval. Alternatively, copy number variants can be detected by sequencing a mate-paired library providing positional information from both ends of the interval. Deletions can be detected by mate-pairs spanning a larger genomic segment than anticipated based on the library size. Yellow boxes/vertical lines represent BACs and SNPs, respectively, showing normal copies compared to the reference genome, whereas the red box/vertical lines represent (part of) the BAC/SNPs that show a deletion compared to the reference genome. Grey boxes represent individual sequence reads. Split-reads (C) are indicated by red boxes and connected by a dotted red lines. Appropriately mapped mate-pairs (D) according to the size selected for are shown in grey boxes and connected by solid black lines indicating the distance between the pairs. Mate-pairs that map at outside the size distribution are shown in red boxes, connected by red solid lines.

addition, new high-throughput approaches such as array CGH were developed that facilitated and notably accelerated the analysis of the human genome on a large scale, including the detection of an unprecedented level of CNV within it. Together, these approaches have contributed significantly to the rapid development of molecular karyotyping, which allows disease phenotypes to be directly linked to gene dosage alterations.

The concept of molecular karyotyping has significantly changed the field of clinical cytogenetics and clinical diagnostics in this decennium. The ability to obtain detailed quantitative copy number information has already led to a significant improvement in diagnostic yield in patients with MR and is likely to do so for other common diseases such as autism, epilepsy, and schizophrenia. ${ }^{83-87}$ The genetic basis of several clinical syndromes has been uncovered by this approach and novel microdeletion and microduplication syndromes have been identified from clinically heterogeneous cohorts. Without any doubt, the implementation of next generation sequencing technologies and medical resequencing strategies will continue to change clinical genetic research and diagnostics. ${ }^{76} 8889$ Eventually, up to $25 \%$ of all cases of MR may be explained by copy number dependent gene dosage variations, although not all of these variants will be fully penetrant, challenging clinical interpretation. In addition, high throughput (re-)sequencing may reveal disease associated variants in another $10-30 \%$ of cases. Clinical and biological interpretation of these variants will require large international and multidisciplinary collaborative efforts.

Acknowledgements This work was supported by grants from the Netherlands Organisation for Health Research and Development (ZonMW 916.86.016 to LELMV, ZonMW 917.86.319 to BBAdV, ZonMW 917.66.363 to JAV), grants from the AnEUploidy project (LSHG-CT-2006-037627 to BBAdV and JAV) supported by the European Commission under FP6.
Funding Other funders: Netherlands Organisation for Health Research and Development and European Commission under FP6.

Competing interests None.

Provenance and peer review Not commissioned; externally peer reviewed.

\section{REFERENCES}

1. Solinas-Toldo $\mathbf{S}$, Lampel $\mathrm{S}$, Stilgenbauer $\mathrm{S}$, Nickolenko J, Benner A, Döhner $\mathrm{H}$, Cremer T, Lichter P. Matrix-based comparative genomic hybridization: biochips to screen for genomic imbalances. Genes Chromosomes Cancer 1997:20:399-407.

2. Pinkel D, Segraves R, Sudar D, Clark S, Poole I, Kowbel D, Collins C, Kuo WL, Chen C, Zhai Y, Dairkee SH, Ljung BM, Gray JW, Albertson DG. High resolution analysis of DNA copy number variation using comparative genomic hybridization to microarrays. Nat Genet 1998;20:207-11.

3. Koolen DA, Pfundt R, de Leeuw N, Hehir-Kwa JY, Nillesen WM, Neefs I, Scheltinga I, Sistermans E, Smeets D, Brunner HG, Geurts van Kessel A, Veltman $\mathrm{JA}$, de Vries BB. Genomic microarrays in mental retardation: a practical workflow for diagnostic applications. Hum Mutat 2009:30:283-92.

4. Menten B, Maas N, Thienpont B, Buysse K, Vandesompele J, Melotte C, de Rave T, Van Vooren S, Balikova I, Backx L, Janssens S, De Paepe A, De Moor B, Moreau Y, Marynen P, Fryns JP, Mortier G, Devriendt K, Speleman F, Vermeesch JR. Emerging patterns of cryptic chromosomal imbalance in patients with idiopathic mental retardation and multiple congenital anomalies: a new series of 140 patients and review of published reports. J Med Genet 2006:43:625-33.

5. Redon R, Ishikawa S, Fitch KR, Feuk L, Perry GH, Andrews TD, Fiegler H, Shapero MH, Carson AR, Chen W, Cho EK, Dallaire S, Freeman JL, González JR, Gratacòs M, Huang J, Kalaitzopoulos D, Komura D, MacDonald JR, Marshall CR, Mei R, Montgomery L, Nishimura K, Okamura K, Shen F, Somerville MJ, Tchinda J, Valsesia A, Woodwark C, Yang F, Zhang J, Zerjal T, Zhang J, Armengol L, Conrad DF, Estivill X, Tyler-Smith C, Carter NP, Aburatani H, Lee C, Jones KW, Scherer SW, Hurles ME. Global variation in copy number in the human genome. Nature 2006:444:444-54.

6. Rosenberg C, Knijnenburg J, Bakker E, Vianna-Morgante AM, Sloos W, Otto PA, Kriek M, Hansson K, Krepischi-Santos AC, Fiegler H, Carter NP, Bijlsma EK, van Haeringen A, Szuhai K, Tanke HJ. Array-CGH detection of micro rearrangements in mentally retarded individuals: clinical significance of imbalances present both in affected children and normal parents. J Med Genet 2006;43:180-6.

7. Schoumans J, Ruivenkamp C, Holmberg E, Kyllerman M, Anderlid BM, Nordenskjöld M. Detection of chromosomal imbalances in children with idiopathic 
mental retardation by array based comparative genomic hybridisation (array-CGH). J Med Genet 2005; 42:699-705.

8. Shaw-Smith C, Redon R, Rickman L, Rio M, Willatt L, Fiegler H, Firth H, Sanlaville D, Winter R, Colleaux L, Bobrow M, Carter NP. Microarray based comparative genomic hybridisation (array-CGH) detects submicroscopic chromosomal deletions and duplications in patients with learning disability/mental retardation and dysmorphic features. J Med Genet 2004;41:241-8.

9. Vissers LE, de Vries BB, Osoegawa K, Janssen IM, Feuth T, Choy CO, Straatman H, van der Vliet W, Huys EH, van Rijk A, Smeets D, van Ravenswaaii-Arts CM, Knoers NV, van der Burgt I, de Jong PJ, Brunner HG, Geurts van Kessel A, Schoenmakers EF, Veltman JA. Array-based comparative genomic hybridization for the genomewide detection of submicroscopic chromosomal abnormalities. Am J Hum Genet 2003;73:1261-70.

10. de Vries BB, Pfundt $R$, Leisink M, Koolen DA, Vissers LE, Janssen IM, Reijmersdal S, Nillesen WM, Huys EH, Leeuw N, Smeets D, Sistermans EA, Feuth T, van Ravenswaaij-Arts CM, Geurts van Kessel A, Schoenmakers EF, Brunner HG, Veltman JA. Diagnostic genome profiling in mental retardation. Am J Hum Genet 2005;77:606-16

11. Hehir-Kwa JY, Egmont-Petersen M, Janssen IM, Smeets D, van Kessel AG, Veltman JA. Genome-wide copy number profiling on high-density bacterial artificial chromosomes, single-nucleotide polymorphisms, and oligonucleotide microarrays: a platform comparison based on statistical power analysis. DNA Res 2007; 14:1-11.

12. Friedman JM, Baross A, Delaney AD, Ally A, Arbour L, Armstrong L, Asano J, Bailey DK, Barber S, Birch P, Brown-John M, Cao M, Chan S, Charest DL, Farnoud N, Fernandes N, Flibotte S, Go A, Gibson WT, Holt RA, Jones SJ, Kennedy GC, Krzywinski M, Langlois S, Li HI, McGillivray BC, Nayar T, Pugh TJ, Rajcan-Separovic E, Schein JE, Schnerch A, Siddiqui A, Van Allen MI, Wilson G, Yong SL, Zahir F, Eydoux P, Marra MA. Oligonucleotide microarray analysis of genomic imbalance in children with mental retardation. Am J Hum Genet 2006;79:500-13.

13. Wagenstaller J, Spranger S, Lorenz-Depiereux B, Kazmierczak B, Nathrath M, Wahl D, Heye B, Glaser D, Liebscher V, Meitinger T, Strom TM. Copy-number variations measured by single-nucleotide-polymorphism oligonucleotide arrays in patients with mental retardation. Am J Hum Genet 2007;81:768-79.

14. McMullan DJ, Bonin M, Hehir-Kwa JY, de Vries BB, Dufke A, Rattenberry E, Steehouwer M, Moruz L, Pfundt R, de Leeuw N, Riess A, Altug-Teber O, Enders H, Singer S, Grasshoff U, Walter M, Walker JM, Lamb CV, Davison EV, Brueton L, Riess 0, Veltman JA. Molecular karyotyping of patients with unexplained mental retardation by SNP arrays: a multicenter study. Hum Mutat 2009:30:1082-92.

15. Zhang ZF, Ruivenkamp C, Staaf J, Zhu H, Barbaro M, Petillo D, Khoo SK, Borg A, Fan YS, Schoumans J. Detection of submicroscopic constitutional chromosome aberrations in clinical diagnostics: a validation of the practical performance of different array platforms. Eur J Hum Genet 2008;16:786-92.

16. Shao L, Shaw CA, Lu XY, Sahoo T, Bacino CA, Lalani SR, Stankiewicz P, Yatsenko SA, Li Y, Neill S, Pursley AN, Chinault AC, Patel A, Beaudet AL, Lupski JR, Cheung $\mathrm{SW}$. Identification of chromosome abnormalities in subtelomeric regions by microarray analysis: a study of 5,380 cases. Am J Med Genet $A$ 2008; 146A:2242-51.

17. Gijsbers AC, Lew JY, Bosch CA, Schuurs-Hoeijmakers JH, van Haeringen A, den Hollander NS, Kant SG, Bijlsma EK, Breuning MH, Bakker E, Ruivenkamp CA. A new diagnostic workflow for patients with mental retardation and/or multiple congenital abnormalities: test arrays first. Eur J Hum Genet 2009;17:1394-402.

18. Roeleveld N, Zielhuis GA, Gabreels F. The prevalence of mental retardation: a critical review of recent literature. Dev Med Child Neurol 1997;39:125-32.

19. Yeargin-Allsopp M, Murphy CC, Cordero JF, Decouflé P, Hollowell JG. Reported biomedical causes and associated medical conditions for mental retardation among 10-year-old children, metropolitan Atlanta, 1985 to 1987. Dev Med Child Neurol 1997;39:142-9.

20. Anderson G, Schroer RJ, Stevenson RE. Mental retardation in South Carolina. II. Causation. In: Saul RA, Phelan MC, eds. Proceedings of the Greenwood genetic center. Greenwood, South Carolina, USA: Greenwood Genetic Centre 1996.

21. de Vries BB, van den Ouweland AM, Mohkamsing S, Duivenvoorden HJ, Mol E, Gelsema K, van Rijn M, Halley DJ, Sandkuijl LA, Oostra BA, Tibben A, Niermeijer MF. Screening and diagnosis for the fragile $X$ syndrome among the mentally retarded: an epidemiological and psychological survey. Collaborative Fragile X Study Group. Am J Hum Genet 1997:61:660-7.

22. Schouten JP, McElgunn CJ, Waaijer R, Zwijnenburg D, Diepvens F, Pals G. Relative quantification of 40 nucleic acid sequences by multiplex ligation-dependent probe amplification. Nucleic Acids Res 2002;30:57.

23. de Vries BB, Winter R, Schinzel A, van Ravenswaaij-Arts C. Telomeres: a diagnosis at the end of the chromosomes. J Med Genet 2003;40:385-98.

24. Flint J, Wilkie AO, Buckle VJ, Winter RM, Holland AJ, McDermid HE. The detection of subtelomeric chromosomal rearrangements in idiopathic mental retardation. Nat Genet 1995; 9:132-40

25. Knight SJ, Regan R, Nicod A, Horsley SW, Kearney L, Homfray T, Winter RM, Bolton P, Flint J. Subtle chromosomal rearrangements in children with unexplained mental retardation. Lancet 1999;354:1676-81.

26. Koolen DA, Nillesen WM, Versteeg MH, Merkx GF, Knoers NV, Kets M, Vermeer S, van Ravenswaaij CM, de Kovel CG, Brunner HG, Smeets D, de Vries BB, Sistermans EA. Screening for subtelomeric rearrangements in 210 patients with unexplained mental retardation using multiplex ligation dependent probe amplification (MLPA). J Med Genet 2004;41:892-9.
27. Tyson C, Harvard C, Locker R, Friedman JM, Langlois S, Lewis ME, Van Allen M, Somerville M, Arbour L, Clarke L, McGilivray B, Yong SL, Siegel-Bartel J, Rajcan-Separovic E. Submicroscopic deletions and duplications in individuals with intellectual disability detected by array-CGH. Am J Med Genet A 2005;139:173-85.

28. Veltman JA. Genomic microarrays in clinical diagnosis. Curr Opin Pediatr 2006:18:598-603.

29. Knight SJ, Regan R. Idiopathic learning disability and genome imbalance. Cytogenet Genome Res 2006;115:215-24.

30. Iafrate AJ, Feuk L, Rivera MN, Listewnik ML, Donahoe PK, Oi Y, Scherer SW, Lee C. Detection of large-scale variation in the human genome. Nat Genet 2004;36:949-51.

31. Conrad DF, Andrews TD, Carter NP, Hurles ME, Pritchard JK. A high-resolution survey of deletion polymorphism in the human genome. Nat Genet 2006;38:75-81.

32. Hinds DA, Kloek AP, Jen M, Chen X, Frazer KA. Common deletions and SNPs are in linkage disequilibrium in the human genome. Nat Genet 2006;38:82-5.

33. McCarroll SA.Hadnott TN, Perry GH, Sabeti PC, Zody MC, Barrett JC, Dallaire S, Gabriel SB, Lee C, Daly MJ, Altshuler DM. International HapMap Consortium. Common deletion polymorphisms in the human genome. Nat Genet 2006; 38:86-92.

34. Sebat J, Lakshmi B, Troge J, Alexander J, Young J, Lundin P, Månér S, Massa H, Walker M, Chi M, Navin N, Lucito R, Healy J, Hicks J, Ye K, Reiner A, Gilliam TC, Trask B, Patterson N, Zetterberg A, Wigler M. Large-scale copy number polymorphism in the human genome. Science 2004:305:525-8.

35. Sharp AJ, Locke DP, McGrath SD, Cheng Z, Bailey JA, Vallente RU, Pertz LM, Clark RA, Schwartz S, Segraves R, Oseroff W, Albertson DG, Pinkel D, Eichler EE. Segmental duplications and copy-number variation in the human genome. Am J Hum Genet 2005;77:78-88.

36. Tuzun E, Sharp AJ, Bailey JA, Kaul R, Morrison VA, Pertz LM, Haugen E, Hayden H, Albertson D, Pinkel D, Olson MV, Eichler EE. Fine-scale structural variation of the human genome. Nat Genet 2005;37:727-32.

37. Wirtenberger $\mathbf{M}$, Hemminki K, Burwinkel B. Identification of frequent chromosome copy-number polymorphisms by use of high-resolution single-nucleotidepolymorphism arrays. Am J Hum Genet 2006; 78:520-2.

38. Pinto D, Marshall C, Feuk L, Scherer SW. Copy-number variation in control population cohorts. Hum Mol Genet 2007;16(Spec No. 2):168-73.

39. Perry GH, Ben-Dor A, Tsalenko A, Sampas N, Rodriguez-Revenga L, Tran CW, Scheffer A, Steinfeld I, Tsang P, Yamada NA, Park HS, Kim JI, Seo JS, Yakhini Z, Laderman S, Bruhn L, Lee C. The fine-scale and complex architecture of human copy-number variation. Am J Hum Genet 2008:82:685-95.

40. Levy S, Sutton G, Ng PC, Feuk L, Halpern AL, Walenz BP, Axelrod N, Huang J, Kirkness EF, Denisov G, Lin Y, MacDonald JR, Pang AW, Shago M, Stockwell TB, Tsiamouri A, Bafna V, Bansal V, Kravitz SA, Busam DA, Beeson KY, McIntosh TC, Remington KA, Abril JF, Gill J, Borman J, Rogers YH, Frazier ME, Scherer SW, Strausberg RL, Venter JC. The diploid genome sequence of an individual human. PLOS Biol 2007:5:e254.

41. Conrad DF, Pinto D, Redon R, Feuk L, Gokcumen O, Zhang Y, Aerts J, Andrews TD, Barnes C, Campbell P, Fitzgerald T, Hu M, Ihm CH, Kristiansson K, Macarthur DG, Macdonald JR, Onyiah I, Pang AW, Robson S, Stirrups K, Valsesia A, Walter K, Wei J, Tyler-Smith C, Carter NP, Lee C, Scherer SW, Hurles ME. The Wellcome Trust Case Control Consortium. Origins and functional impact of copy number variation in the human genome. Nature 2009. doi:10.1038/nature08516.

42. Lee C, lafrate AJ, Brothman AR. Copy number variations and clinical cytogenetic diagnosis of constitutional disorders. Nat Genet 2007;39:S48-54.

43. Conrad DF, Hurles ME. The population genetics of structural variation. Nat Genet 2007:39:S30-6.

44. Lupski JR. Genomic rearrangements and sporadic disease. Nat Genet 2007;39:43-7.

45. Lu XY, Phung MT, Shaw CA, Pham K, Neil SE, Patel A, Sahoo T, Bacino CA Stankiewicz P, Kang SH, Lalani S, Chinault AC, Lupski JR, Cheung SW, Beaudet AL. Genomic imbalances in neonates with birth defects: high detection rates by using chromosomal microarray analysis. Pediatrics 2008:122:1310-18.

46. Bruder CE, Piotrowski A, Gijsbers AA, Andersson R, Erickson S, de Ståhl TD, Menzel U, Sandgren J, von Tell D, Poplawski A, Crowley M, Crasto C, Partridge EC, Tiwari H, Allison DB, Komorowski J, van Ommen GJ, Boomsma DI, Pedersen NL, den Dunnen JT, Wirdefeldt K, Dumanski JP. Phenotypically concordant and discordant monozygotic twins display different DNA copy-number-variation profiles. Am J Hum Genet 2008:82:763-71.

47. Shaffer LG, Theisen A, Bejjani BA, Ballif BC, Aylsworth AS, Lim C, McDonald M, Ellison JW, Kostiner D, Saitta S, Shaikh T. The discovery of microdeletion syndromes in the post-genomic era: review of the methodology and characterization of a new 1q41q42 microdeletion syndrome. Genet Med 2007:9:607-16

48. Koolen DA, Vissers LE, Pfundt R, de Leeuw N, Knight SJ, Regan R, Kooy RF, Reyniers E, Romano C, Fichera M, Schinzel A, Baumer A, Anderlid BM, Schoumans J, Knoers NV, Geurts van Kessel A, Sistermans EA, Veltman JA, Brunner HG, de Vries BB. A new chromosome 17q21.31 microdeletion syndrome associated with a common inversion polymorphism. Nat Genet 2006;38:999-1001.

49. Sharp AJ, Hansen S, Selzer RR, Cheng Z, Regan R, Hurst JA, Stewart H, Price SM, Blair E, Hennekam RC, Fitzpatrick CA, Segraves R, Richmond TA, Guiver C, Albertson DG, Pinkel D, Eis PS, Schwartz S, Knight SJ, Eichler EE. Discovery of previously unidentified genomic disorders from the duplication architecture of the human genome. Nat Genet 2006;38:1038-42. 
50. Shaw-Smith C, Pittman AM, Willatt L, Martin H, Rickman L, Gribble S, Curley R, Cumming S, Dunn C, Kalaitzopoulos D, Porter K, Prigmore E, Krepischi-Santos AC, Varela MC, Koiffmann CP, Lees AJ, Rosenberg C, Firth HV, de Silva R, Carter NP. Microdeletion encompassing MAPT at chromosome 17q21.3 is associated with developmental delay and learning disability. Nat Genet 2006;38:1032-7.

51. Koolen DA, Sharp AJ, Hurst JA, Firth HV, Knight SJ, Goldenberg A, Saugier-Veber P. Pfundt $R$, Vissers LE, Destrée A, Grisart B, Rooms L, Van der Aa N, Field M, Hackett A, Bell K, Nowaczyk MJ, Mancini GM, Poddighe PJ, Schwartz CE, Rossi E, De Gregori M, Antonacci-Fulton LL, McLellan MD 2nd, Garrett JM, Wiechert MA, Miner TL, Crosby S, Ciccone R, Willatt L, Rauch A, Zenker M, Aradhya S, Manning MA, Strom TM, Wagenstaller J, Krepischi-Santos AC, Vianna-Morgante AM, Rosenberg C, Price SM, Stewart H, Shaw-Smith C, Brunner HG, Wilkie AO, Veltman $\mathrm{JA}$, Zuffardi $\mathrm{O}$, Eichler EE, de Vries BB. Clinical and molecular delineation of the 17q21.31 microdeletion syndrome. J Med Genet 2008:45:710-20.

52. Sharp AJ, Selzer RR, Veltman JA, Gimelli S, Gimelli G, Striano P, Coppola A, Regan R, Price SM, Knoers NV, Eis PS, Brunner HG, Hennekam RC, Knight SJ, de Vries BB, Zuffardi O, Eichler EE. Characterization of a recurrent $15 q 24$ microdeletion syndrome. Hum Mol Genet 2007:16:567-72.

53. Klopocki E, Graul-Neumann LM, Grieben U, Tönnies H, Ropers HH, Horn D, Mundlos S, Ullmann R. A further case of the recurrent 15q24 microdeletion syndrome, detected by array CGH. Eur J Pediatr 2008;167:903-8.

54. El-Hattab AW, Smolarek TA, Walker ME, Schorry EK, Immken LL, Patel G, Abbott MA, Lanpher BC, Ou Z, Kang SH, Patel A, Scaglia F, Lupski JR, Cheung SW, Stankiewicz P. Redefined genomic architecture in $15 q 24$ directed by patient deletion/duplication breakpoint mapping. Hum Genet 2009;126:589-602.

55. Mefford HC, Sharp AJ, Baker C, Itsara A, Jiang Z, Buysse K, Huang S, Maloney VK, Crolla JA, Baralle D, Collins A, Mercer C, Norga K, de Ravel T, Devriendt K, Bongers EM, de Leeuw N, Reardon W, Gimelli S, Bena F. Hennekam RC, Male A, Gaunt L, Clayton-Smith J, Simonic I, Park SM, Mehta SG, Nik-Zainal S, Woods CG, Firth HV, Parkin G, Fichera M, Reitano S, Lo Giudice M, Li KE, Casuga I, Broomer A, Conrad B, Schwerzmann M, Räber L, Gallati S, Striano P, Coppola A, Tolmie JL, Tobias ES, Lilley C, Armengol L, Spysschaert Y, Verloo P, De Coene A, Goossens L, Mortier G, Speleman F, van Binsbergen E, Nelen MR, Hochstenbach R, Poot M, Gallagher L, Gill M, McClellan J, King MC, Regan R, Skinner C, Stevenson RE, Antonarakis SE, Chen C, Estivill X, Menten B, Gimelli G, Gribble S, Schwartz S, Sutcliffe JS, Walsh T, Knight SJ, Sebat J, Romano C, Schwartz CE, Veltman JA, de Vries BB, Vermeesch JR, Barber JC, Willatt L, Tassabehii M, Eichler EE. Recurrent rearrangements of chromosome 1q21.1 and variable pediatric phenotypes. N Engl J Med 2008;359:1685-99.

56. Brunetti-Pierri N, Berg JS, Scaglia F, Belmont J, Bacino CA, Sahoo T, Lalani SR, Graham B, Lee B, Shinawi M, Shen J, Kang SH, Pursley A, Lotze T, Kennedy G, Lansky-Shafer S, Weaver C, Roeder ER, Grebe TA, Arnold GL, Hutchison T, Reimschisel T, Amato S, Geragthy MT, Innis JW, Obersztyn E, Nowakowska B, Rosengren SS, Bader PI, Grange DK, Naqvi S, Garnica AD, Bernes SM, Fong CT, Summers A, Walters WD, Lupski JR, Stankiewicz P, Cheung SW, Patel A. Recurrent reciprocal 1q21.1 deletions and duplications associated with microcephaly or macrocephaly and developmental and behavioral abnormalities. Nat Genet 2008;40:1466-71.

57. Sharp AJ, Mefford HC, Li K, Baker C, Skinner C, Stevenson RE, Schroer RJ, Novara F, De Gregori M, Ciccone R, Broomer A, Casuga I, Wang Y, Xiao C, Barbacioru C, Gimelli G, Bernardina BD, Torniero C, Giorda R, Regan R, Murday V, Mansour S, Fichera M, Castiglia L, Failla P, Ventura M, Jiang Z, Cooper GM, Knight SJ, Romano C, Zuffardi O, Chen C, Schwartz CE, Eichler EE. A recurrent 15q13.3 microdeletion syndrome associated with mental retardation and seizures. Nat Genet 2008; $40: 322-8$

58. van Bon BW, Mefford HC, Menten B, Koolen DA, Sharp AJ, Nillesen WM, Innis JW, de Ravel TJ, Mercer CL, Fichera M, Stewart H, Connell LE, Ounap K, Lachlan K, Castle B, Van der Aa N, van Ravenswaaii C, Nobrega MA, Serra-Juhé C, Simonic I, de Leeuw N, Pfundt R, Bongers EM, Baker C, Finnemore P, Huang S, Maloney VK, Crolla JA, van Kalmthout M, Elia M, Vandeweyer G, Fryns JP, Janssens S, Foulds N, Reitano S, Smith K, Parkel S, Loeys B, Woods CG, Oostra A, Speleman F, Pereira AC, Kurg A, Willatt L, Knight SJ, Vermeesch JR, Romano C, Barber JC, Mortier G, Pérez-Jurado LA, Kooy F, Brunner HG, Eichler EE, Kleefstra T, de Vries BB. Further delineation of the $15 q 13$ microdeletion and duplication syndromes: a clinical spectrum varying from non-pathogenic to a severe outcome. J Med Genet 2009; $46: 511-23$

59. Hannes FD, Sharp AJ, Mefford HC, de Ravel T, Ruivenkamp CA, Breuning MH, Fryns JP, Devriendt K, Van Buggenhout G, Vogels A, Stewart H, Hennekam RC, Cooper GM, Regan R, Knight SJ, Eichler EE, Vermeesch JR. Recurrent reciprocal deletions and duplications of $16 p 13.11$ : the deletion is a risk factor for MR/MCA while the duplication may be a rare benign variant. J Med Genet 2009;46:223-32

60. Ullmann R, Turner G, Kirchhoff M, Chen W, Tonge B, Rosenberg C, Field M, Vianna-Morgante AM, Christie L, Krepischi-Santos AC, Banna L, Brereton AV, Hill A, Bisgaard AM, Müller I, Hultschig C, Erdogan F, Wieczorek G, Ropers HH. Array CGH identifies reciprocal 16p13.1 duplications and deletions that predispose to autism and/or mental retardation. Hum Mutat 2007;28:674-82.

61. Stefansson H, Rujescu D, Cichon S, Pietiläinen OP, Ingason A, Steinberg S, Fossdal R, Sigurdsson E, Sigmundsson T, Buizer-Voskamp JE, Hansen T, Jakobsen KD, Muglia P, Francks C, Matthews PM, Gylfason A, Halldorsson BV, Gudbjartsson D, Thorgeirsson TE, Sigurdsson A, Jonasdottir A, Jonasdottir A, Bjornsson A Mattiasdottir S, Blondal T, Haraldsson M, Magnusdottir BB, Giegling I, Möller HJ, Hartmann A, Shianna KV, Ge D, Need AC, Crombie C, Fraser G, Walker N, Lonnqvist
J, Suvisaari J, Tuulio-Henriksson A, Paunio T, Toulopoulou T, Bramon E, Di Forti M Murray R, Ruggeri M, Vassos E, Tosato S, Walshe M, Li T, Vasilescu C, Mühleisen TW, Wang AG, Ullum H, Djurovic S, Melle I, Olesen J, Kiemeney LA, Franke B, Group Sabatti C, Freimer NB, Gulcher JR, Thorsteinsdottir U, Kong A, Andreassen OA, Ophoff RA, Georgi A, Rietschel M, Werge T, Petursson H, Goldstein DB, Nöthen MM, Peltonen L, Collier DA, St Clair D, Stefansson K. Large recurrent microdeletions associated with schizophrenia. Nature 2008:455:232-6.

62. International Schizophrenia Consortium. Rare chromosomal deletions and duplications increase risk of schizophrenia. Nature 2008:455:237-41.

63. Miller DT, Shen Y, Weiss LA, Korn J, Anselm I, Bridgemohan C, Cox GF, Dickinson H, Gentile J, Harris DJ, Hegde V, Hundley R, Khwaja O, Kothare S, Luedke C, Nasi R, Poduri A, Prasad K, Raffalli P, Reinhard A, Smith SE, Sobeih MM, Soul JS, Stoler J, Takeoka M, Tan WH, Thakuria J, Wolff R, Yusupov R, Gusella JF, Daly MJ, Wu BL. Microdeletion/duplication at 15q13.2q13.3 among individuals with features of autism and other neuropsychiatric disorders. J Med Genet 2009:46:242-8.

64. Vissers LE, van Ravenswaaij CM, Admiraal R, Hurst JA, de Vries BB, Janssen IM van der Vliet WA, Huys EH, de Jong PJ, Hamel BC, Schoenmakers EF, Brunner HG, Veltman JA, Geurts van Kessel A. Mutations in a new member of the chromodomain gene family cause CHARGE syndrome. Nat Genet 2004;36:955-7.

65. Blake KD, Davenport SL, Hall BD, Hefner MA, Pagon RA, Williams MS, Lin AE, Graham JM Jr. CHARGE association: an update and review for the primary pediatrician. Clin Pediatr (Phila) 1998;37:159-73.

66. Pagon RA, Graham JM Jr, Zonana J, Yong SL. Coloboma, congenital heart disease, and choanal atresia with multiple anomalies: CHARGE association. J Pediatr 1981;99:223-7.

67. Hurst JA, Meinecke P, Baraitser M. Balanced $t(6 ; 8)(6 p 8 p ; 6 q 8 q)$ and the CHARGE association. J Med Genet 1991;28:54-5.

68. Harada N, Visser R, Dawson A, Fukamachi M, Iwakoshi M, Okamoto N, Kishino T, Niikawa N, Matsumoto N. A 1-Mb critical region in six patients with 9q34.3 terminal deletion syndrome. J Hum Genet 2004;49:440-4

69. Kleefstra T, van Zelst-Stams WA, Nillesen WM, Cormier-Daire V, Houge G, Foulds $\mathrm{N}$, van Dooren $\mathrm{M}$, Willemsen $\mathrm{MH}$, Pfundt $\mathrm{R}$, Turner $\mathrm{A}$, Wilson M, McGaughran $\mathrm{J}$, Rauch A, Zenker M, Adam MP, Innes M, Davies C, López AG, Casalone R, Weber A, Brueton LA, Navarro AD, Bralo MP, Venselaar H, Stegmann SP, Yntema HG, van Bokhoven $\mathrm{H}$, Brunner $\mathrm{HG}$. Further clinical and molecular delineation of the 9q Subtelomeric Deletion Syndrome supports a major contribution of EHMT1 haploinsufficiency to the core phenotype. J Med Genet 2009:46:598-606.

70. Stewart DR, Huang A, Faravelli F, Anderlid BM, Medne L, Ciprero K, Kaur M, Ross E, Tenconi R, Nordenskjöld M, Gripp KW, Nicholson L, Meschino WS, Capua E, Quarrell OW, Flint J, Irons M, Giampietro PF, Schowalter DB, Zaleski CA, Malacarne M, Zackai EH, Spinner NB, Krantz ID. Subtelomeric deletions of chromosome 9q: a novel microdeletion syndrome. Am J Med Genet A 2004:128A:340-51.

71. Yatsenko SA, Cheung SW, Scott DA, Nowaczyk MJ, Tarnopolsky M, Naidu S, Bibat G, Patel A, Leroy JG, Scaglia F, Stankiewicz P, Lupski JR. Deletion 9q34.3 syndrome: genotype-phenotype correlations and an extended deletion in a patient with features of Opitz C trigonocephaly. J Med Genet 2005;42:328-35.

72. Kleefstra T, Smidt M, Banning MJ, Oudakker AR, Van Esch H, de Brouwer AP, Nillesen W, Sistermans EA, Hamel BC, de Bruijn D, Fryns JP, Yntema HG, Brunner HG, de Vries BB, van Bokhoven H. Disruption of the gene Euchromatin Histone Methyl Transferase1 (Eu-HMTase1) is associated with the 9q34 subtelomeric deletion syndrome. J Med Genet 2005;42:299-306.

73. Kleefstra T, Koolen DA, Nillesen WM, de Leeuw N, Hamel BC, Veltman JA, Sistermans $E A$, van Bokhoven $H$, van Ravenswaay $C$, de Vries BB. Interstitial $2.2 \mathrm{Mb}$ deletion at $9 \mathrm{q} 34$ in a patient with mental retardation but without classical features of the 9q subtelomeric deletion syndrome. Am J Med Genet $A$ 2006:140:618-23.

74. Vissers LE, Veltman JA, van Kessel AG, Brunner HG. Identification of disease genes by whole genome CGH arrays. Hum Mol Genet 2005;14(Spec No. 2): R215-23

75. Rusk N, Kiermer V. Primer: sequencing-the next generation. Nat Methods 2008;5:15.

76. Mardis ER. Next-generation DNA sequencing methods. Annu Rev Genomics Hum Genet 2008;9:387-402.

77. Wheeler DA, Srinivasan M, Egholm M, Shen Y, Chen L, McGuire A, He W, Chen YJ, Makhijani V, Roth GT, Gomes X, Tartaro K, Niazi F, Turcotte CL, Irzyk GP, Lupski JR, Chinault C, Song XZ, Liu Y, Yuan Y, Nazareth L, Din X, Muzny DM, Margulies M, Weinstock GM, Gibbs RA, Rothberg JM. The complete genome of an individual by massively parallel DNA sequencing. Nature 2008;452:872-6.

78. Korbel Jo, Urban AE, Affourtit JP, Godwin B, Grubert F, Simons JF, Kim PM, Palejev D, Carriero NJ, Du L, Taillon BE, Chen Z, Tanzer A, Saunders AC, Chi J, Yang F, Carter NP, Hurles ME, Weissman SM, Harkins TT, Gerstein MB, Egholm M, Snyder M. Paired-end mapping reveals extensive structural variation in the human genome. Science 2007;318:420-6.

79. Kidd JM, Cooper GM, Donahue WF, Hayden HS, Sampas N, Graves T, Hansen N, Teague B, Alkan C, Antonacci F, Haugen E, Zerr T, Yamada NA, Tsang P. Newman TL, Tüzün E, Cheng Z, Ebling HM, Tusneem N, David R, Gillett W, Phelps KA, Weaver M, Saranga D, Brand A, Tao W, Gustafson E, McKernan K, Chen L, Malig M, Smith JD, Korn JM, McCarroll SA, Altshuler DA, Peiffer DA, Dorschner M, Stamatoyannopoulos J, Schwartz D, Nickerson DA, Mullikin JC, Wilson RK, Bruhn L, Olson MV, Kaul R, Smith DR, Eichler EE. Mapping and sequencing of structural variation from eight human genomes. Nature 2008:453:56-64. 
80. Tarpey PS, Smith R, Pleasance E, Whibley A, Edkins S, Hardy C, O'Meara S, Latimer C, Dicks E, Menzies A, Stephens P, Blow M, Greenman C, Xue Y, Tyler-Smith C, Thompson D, Gray K, Andrews J, Barthorpe S, Buck G, Cole J, Dunmore R, Jones D, Maddison M, Mironenko T, Turner R, Turrell K, Varian J, West S, Widaa S, Wray P, Teague J, Butler A, Jenkinson A, Jia M, Richardson D, Shepherd R, Wooster R, Tejada MI, Martinez F, Carvill G, Goliath R, de Brouwer AP, van Bokhoven H, Van Esch H, Chelly J, Raynaud M, Ropers HH, Abidi FE, Srivastava AK, Cox J, Luo Y, Mallya U, Moon J, Parnau J, Mohammed S, Tolmie JL, Shoubridge C, Corbett M, Gardner A, Haan E, Rujirabanjerd S, Shaw M, Vandeleur L, Fullston T, Easton DF, Boyle J, Partington M, Hackett A, Field M, Skinner C, Stevenson RE, Bobrow M, Turner G, Schwartz CE, Gecz J, Raymond FL, Futreal PA, Stratton MR. A systematic, large-scale resequencing screen of $\mathrm{X}$-chromosome coding exons in mental retardation. Nat Genet 2009;41:535-43.

81. Ng SB, Turner EH, Robertson PD, Flygare SD, Bigham AW, Lee C, Shaffer T, Wong M, Bhattacharjee A, Eichler EE, Bamshad M, Nickerson DA, Shendure J. Targeted capture and massively parallel sequencing of 12 human exomes. Nature 2009;461:272-6.

82. Lander ES, Linton LM, Birren B, Nusbaum C, Zody MC, Baldwin J, Devon K, Dewar K, Doyle M, FitzHugh W, Funke R, Gage D, Harris K, Heaford A, Howland J, Kann L, Lehoczky J, LeVine R, McEwan P, McKernan K, Meldrim J, Mesirov JP, Miranda C, Morris W, Naylor J, Raymond C, Rosetti M, Santos R, Sheridan A, Sougnez C Stange-Thomann N, Stojanovic N, Subramanian A, Wyman D, Rogers J, Sulston J, Ainscough R, Beck S, Bentley D, Burton J, Clee C, Carter N, Coulson A, Deadman R, Deloukas P, Dunham A, Dunham I, Durbin R, French L, Grafham D, Gregory S, Hubbard T, Humphray S, Hunt A, Jones M, Lloyd C, McMurray A, Matthews L, Mercer S, Milne S, Mullikin JC, Mungall A, Plumb R, Ross M, Shownkeen R, Sims S, Waterston RH, Wilson RK, Hillier LW, McPherson JD, Marra MA, Mardis ER, Fulton LA, Chinwalla AT, Pepin KH, Gish WR, Chissoe SL, Wendl MC, Delehaunty KD, Miner TL, Delehaunty A, Kramer JB, Cook LL, Fulton RS, Johnson DL, Minx PJ, Clifton SW, Hawkins T, Branscomb E, Predki P, Richardson P, Wenning S, Slezak T, Doggett N, Cheng JF, Olsen A, Lucas S, Elkin C, Uberbacher E, Frazier M, Gibbs RA, Muzny DM, Scherer SE, Bouck JB, Sodergren EJ, Worley KC, Rives CM, Gorrell JH, Metzker ML, Naylor SL, Kucherlapati RS, Nelson DL, Weinstock GM, Sakaki Y, Fujiyama A, Hattori M, Yada T, Toyoda A, Itoh T, Kawagoe C, Watanabe H, Totoki Y, Taylor T, Weissenbach J, Heilig R, Saurin W, Artiguenave F, Brottier P, Bruls T, Pelletier E, Robert C, Wincker P, Smith DR, Doucette-Stamm L, Rubenfield M, Weinstock K, Lee HM, Dubois J, Rosenthal A, Platzer M, Nyakatura G, Taudien S, Rump A, Yang H, Yu J, Wang J, Huang G, Gu J, Hood L, Rowen L, Madan A, Qin S, Davis RW, Federspiel NA, Abola AP, Proctor MJ, Myers RM, Schmutz J, Dickson M, Grimwood J, Cox DR, Olson MV, Kaul R, Raymond C, Shimizu N, Kawasaki K, Minoshima S, Evans GA, Athanasiou M, Schultz R, Roe BA, Chen F, Pan H, Ramser J, Lehrach H, Reinhardt R, McCombie WR, de la Bastide M, Dedhia N, Blöcker H, Hornischer K, Nordsiek G, Agarwala R, Aravind L, Bailey JA, Bateman A, Batzoglou S, Birney E, Bork P, Brown DG, Burge CB, Cerutti L, Chen HC, Church D, Clamp M, Copley RR, Doerks T, Eddy SR, Eichler EE, Furey TS, Galagan J, Gilbert JG, Harmon C, Hayashizaki Y, Haussler D, Hermjakob H, Hokamp K, Jang W, Johnson LS, Jones TA, Kasif S, Kaspryzk A, Kennedy S, Kent WJ, Kitts P, Koonin EV, Korf I, Kulp D, Lancet D, Lowe TM, McLysaght A, Mikkelsen T, Moran JV, Mulder N, Pollara VJ, Ponting CP, Schuler G, Schultz J, Slater G, Smit AF, Stupka E, Szustakowski J, Thierry-Mieg D, Thierry-Mieg J, Wagner L, Wallis J, Wheeler R, Williams A, Wolf YI, Wolfe KH, Yang SP, Yeh RF, Collins F, Guyer MS, Peterson J, Felsenfeld A, Wetterstrand KA, Patrinos A, Morgan MJ, de Jong P, Catanese JJ, Osoegawa K, Shizuya H, Choi S, Chen YJ. International Human Genome Sequencing Consortium. Initial sequencing and analysis of the human genome. Nature 2001;409:860-921.

83. Vrijenhoek T, Buizer-Voskamp JE, van de Stelt I, Strengman E, Sabatti C, Geurts van Kessel A, Brunner HG, Ophoff RA, Veltman JA. Recurrent CNVs disrupt three candidate genes in schizophrenia patients. Am J Hum Genet 2008; 83:504-10.

84. Friedman JI, Vrijenhoek T, MarkX S, Janssen IM, van der Vliet WA, Faas BH, Knoers NV, Cahn W, Kahn RS, Edelmann L, Davis KL, Silverman JM, Brunner HG, van Kessel AG, Wijmenga C, Ophoff RA, Veltman JA. CNTNAP2 gene dosage variation is associated with schizophrenia and epilepsy. Mol Psychiatry 2008:13:261-6.

85. Sebat J, Lakshmi B, Malhotra D, Troge J, Lese-Martin C, Walsh T, Yamrom B, Yoon S, Krasnitz A, Kendall J, Leotta A, Pai D, Zhang R, Lee YH, Hicks J, Spence SJ, Lee AT, Puura K, Lehtimäki T, Ledbetter D, Gregersen PK, Bregman J, Sutcliffe JS, Jobanputra V, Chung W, Warburton D, King MC, Skuse D, Geschwind DH, Gilliam TC, Ye K, Wigler M. Strong association of de novo copy number mutations with autism. Science 2007;316:445-9.
86. Williams R, Lim JE, Harr B, Wing C, Walters R, Distler MG, Teschke M, Wu C, Wiltshire T, Su Al, Sokoloff G, Tarantino LM, Borevitz JO, Palmer AA. A common and unstable copy number variant is associated with differences in Glo1 expression and anxiety-like behavior. PLOS ONE 2009;4:4649.

87. Williams HJ, Owen MJ, O'Donovan MC. Schizophrenia genetics: new insights from new approaches. Br Med Bull 2009;91:61-74.

88. Margulies EH, Cooper GM, Asimenos G, Thomas DJ, Dewey CN, Siepel A, Birney E, Keefe D, Schwartz AS, Hou M, Taylor J, Nikolaev S, Montoya-Burgos J, Löytynoja A, Whelan S, Pardi F, Massingham T, Brown JB, Bickel P, Holmes I, Mullikin JC, Ureta-Vidal A, Paten B, Stone EA, Rosenbloom KR, Kent WJ, Bouffard GG, Guan X, Hansen NF, Idol JR, Maduro W. Maskeri B, McDowell JC, Park M, Thomas PJ, Young AC, Blakesley RW, Muzny DM, Sodergren E, Wheeler DA, Worley KC, Jiang H, Weinstock GM, Gibbs RA, Graves T, Fulton R, Mardis ER, Wilson RK, Clamp M, Cuff J, Gnerre S, Jaffe DB, Chang JL, Lindblad-Toh K, Lander ES, Hinrichs A, Trumbower H, Clawson H, Zweig A, Kuhn RM, Barber G, Harte R, Karolchik D, Field MA, Moore RA, Matthewson CA, Schein JE, Marra MA, Antonarakis SE, Batzoglou S, Goldman N, Hardison R, Haussler D, Miller W, Pachter L, Green ED, Sidow A. Analyses of deep mammalian sequence alignments and constraint predictions for $1 \%$ of the human genome. Genome Res 2007:17:760-74.

89. Fullwood MJ, Wei CL, Liu ET, Ruan Y. Next-generation DNA sequencing of pairedend tags (PET) for transcriptome and genome analyses. Genome Res 2009:19:521-32.

90. Parvari R, Brodyansky I, Elpeleg 0, Moses S, Landau D, Hershkovitz E. A recessive contiguous gene deletion of chromosome 2p16 associated with cystinuria and a mitochondrial disease. Am J Hum Genet 2001;69:869-75.

91. Koppens PF, Hoogenboezem T, Degenhart HJ. CYP21 and CYP21P variability in steroid 21-hydroxylase deficiency patients and in the general population in the Netherlands. Eur J Hum Genet 2000;8:827-36.

92. Rickard S, Parker M, van't Hoff W, Barnicoat A, Russell-Eggitt I, Winter RM, Bitner-Glindzicz M. Oto-facio-cervical (OFC) syndrome is a contiguous gene deletion syndrome involving EYA1: molecular analysis confirms allelism with BOR syndrome and further narrows the Duane syndrome critical region to $1 \mathrm{cM}$. Hum Genet 2001:108:398-403

93. Potocki L, Shaffer LG. Interstitial deletion of 11(p11.2p12): a newly described contiguous gene deletion syndrome involving the gene for hereditary multiple exostoses (EXT2). Am J Med Genet 1996;62:319-25.

94. Bitner-Glindzicz M, Lindley KJ, Rutland P, Blaydon D, Smith W, Milla PJ, Hussain K, Furth-Lavi J, Cosgrove KE, Shepherd RM, Barnes PD, O'Brien RE, Farndon PA Sowden J, Liu XZ, Scanlan MJ, Malcolm S, Dunne MJ, Aynsley-Green A, Glaser B. A recessive contiguous gene deletion causing infantile hyperinsulinism, enteropathy and deafness identifies the Usher type 1C gene. Nat Genet 2000;26:56-60.

95. Menten B, Buysse K, Zahir F, Hellemans J, Hamilton SJ, Costa T, Fagerstrom C, Anadiotis G, Kingsbury D, McGillivray BC, Marra MA, Friedman JM, Speleman F, Mortier G. Osteopoikilosis, short stature and mental retardation as key features of a new microdeletion syndrome on 12q14. J Med Genet 2007:44:264-8.

96. Lesnik Oberstein SA, Kriek M, White SJ, Kalf ME, Szuhai K, den Dunnen JT, Breuning MH, Hennekam RC. Peters Plus syndrome is caused by mutations in B3GALTL, a putative glycosyltransferase. Am J Hum Genet 2006;79:562-6.

97. Brook-Carter PT, Peral B, Ward CJ, Thompson P, Hughes J, Maheshwar MM, Nellist M, Gamble V, Harris PC, Sampson JR. Deletion of the TSC2 and PKD1 genes associated with severe infantile polycystic kidney disease-a contiguous gene syndrome. Nat Genet 1994;8:328-32.

98. Potocki L, Bi W, Treadwell-Deering D, Eifert A, Friedman EM, Glaze D, Krull K, Lee JA, Lewis RA, Mendoza-Londono R, Robbins-Furman P, Shaw C, Shi X, Weissenberger G, Withers M, Yatsenko SA, Zackai EH, Stankiewicz P, Lupski JR. Characterization of Potocki-Lupski syndrome (dup(17)(p11.2p11.2)) and delineation of a dosage-sensitive critical interval that can convey an autism phenotype. Am J Hum Genet 2007; 80:633-49.

99. Zhou J, Gregory MC, Hertz JM, Barker DF, Atkin C, Spencer ES, Tryggvason K. Mutations in the codon for a conserved arginine-1563 in the COL4A5 collagen gene in Alport syndrome. Kidney Int 1993;43:722-9.

100. Van Esch H, Bauters M, Ignatius J, Jansen M, Raynaud M, Hollanders K, Lugtenberg D, Bienvenu T, Jensen LR, Gecz J, Moraine C, Marynen P, Fryns JP, Froyen $\mathrm{G}$. Duplication of the MECP2 region is a frequent cause of severe mental retardation and progressive neurological symptoms in males. Am J Hum Genet 2005; 77:442-53. 